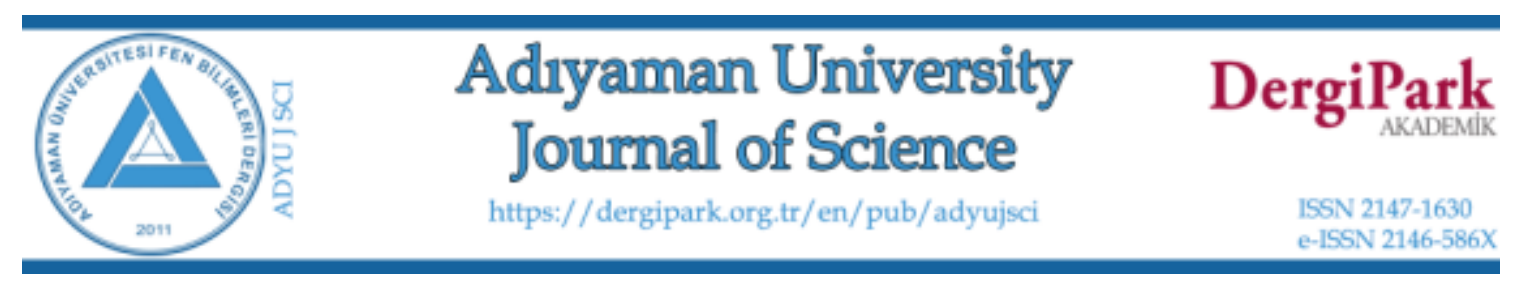

\title{
Reduction of Salmonella Typhimurium, Escherichia coli, and Staphylococcus aureus Biofilms by Electrolysis
}

\author{
Başar KARACA ${ }^{1, *}$ \\ ${ }^{1}$ Ankara University, Faculty of Science, Biology Department, Ankara, Turkey \\ karaca@ankara.edu.tr, ORCID:0000-0001-6943-8965
}

\begin{abstract}
Adherence of microorganisms to food contact surfaces and subsequent biofilm formation leads to equipment damage, food spoilage, and foodborne diseases. Biofilms in food processing plants may exhibit resistance to routine disinfectants and sanitation procedures. Extensive studies have been conducted to reduce the risks of food biofilms. Since electrolysis is an inexpensive and effective approach, it has recently become the focus of interest among researchers in this context. In the related study, the removal (eradication) of major food pathogens such as Escherichia coli, Salmonella Typhimurium and Staphylococcus aureus biofilms was evaluated using low electric current. Experimental studies were conducted in an easy-to-install electrolysis setup containing electrodes capable of integrating metal surfaces on which biofilms develop. E. coli and S. Typhimurium biofilm cells on stainless steel surfaces were eliminated, while a significant decrease (2.5 log reduction) in the number of $S$. aureus biofilm cells was observed in the electrolysis process performed in $2 \mathrm{M} \mathrm{NaCl}$ solution (10 V, $0.3 \mathrm{~A}, 1,2$ and $5 \mathrm{~min})$. The viability of biofilm cells was controlled using colony count method. However, the removal of biofilm matrix residues from the surface was not possible
\end{abstract}


with the preferred electrolysis procedure. The biofilm matrix remaining on the surface after the procedure was detected by the crystal violet binding assay.

Being a low-cost and easy-to-use process, it became clear that electrolysis and the resulting biocidal agents produced by the reactions in the electrolyte buffer can be used in the food industry to control biofilms.

Keywords: Biofilm; Electrolysis; Escherichia coli; Salmonella Typhimurium; Staphylococcus aureus.

\section{Salmonella Typhimurium, Escherichia coli ve Staphylococcus aureus Biyofilmlerinin Elektrolizle Giderimi}

\section{$\ddot{O} z$}

Mikroorganizmaların gidaların temas ettikleri yüzeylere tutunması ve devamında biyofilm üretmeleri, ekipman hasarına, gıda bozulmalarına ve gıda kaynaklı hastalıklara neden olmaktadır. Gıdaların işlendiği çevrelerdeki biyofilmler rutin dezenfektanlara ve sanitasyon işlemlerine direnç gösterebilmektedir. Gıda biyofilmlerinin neden oldukları riskleri azaltmak adına çok sayıda çalışma yürütülmüştür. Bu bağlamda elektroliz, ucuz ve etkili bir yaklaşım olması itibariyle son zamanlarda araştırmacıların odağında bulunmaktadır. İlgili çalışmada önemli gıda patojenleri olan Escherichia coli, Salmonella Typhimurium ve Staphylococcus aureus biyofilmlerinin düşük elektrik akımı ile giderimi (eradikasyon) değerlendirilmiştir. Deneysel çalışmalar, biyofilm örneklerinin geliştirileceği metalik yüzeylerin entegre edilebildiği elektrotları ihtiva eden ve kolaylıkla kurulabilir elektroliz düzeneğinde gerçekleştirilmiştir. $2 \mathrm{M} \mathrm{NaCl}$ çözeltisi tercih edilerek gerçekleştirilen elektroliz işlemiyle (10 V, 0.3 A, 1, 2 ve 5 dakika süresince) paslanmaz çelik yüzeyler üzerindeki $E$. coli ve $S$. Typhimurium biyofilm hücreleri bütünüyle elimine edilirken, $S$. aureus biyofilm hücrelerinin sayısında önemli ölçüde bir azalma saptanmıştır (2.5 log azalma). Biyofilm hücrelerindeki canlılık koloni sayım yöntemiyle kontrol edilmiştir. Ancak biyofilm matriks kalıntılarını yüzeyden bütünüyle temizlemek tercih edilen elektroliz prosedürüyle mümkün olmamıştır. İşlemden sonra yüzeyde kalan matriks yapıları kristal viyole bağlanma uygulamasıyla gösterilmiştir.

Ucuz ve kolay uygulanabilir bir işlem olması itibariyle elektrolizin ve onun sonucunda elektrolit tampondaki reaksiyonlar sonucunda elde edilen biyosidal ajanların gida endüstrisinde biyofilmler mücadelede kullanılabileceği açıkça anlaşılmıştır. 
Anahtar Kelimeler: Biyofilm; Elektroliz; Escherichia coli; Salmonella Typhimurium; Staphylococcus aureus.

\section{Introduction}

The majority of microorganisms organize themselves as biofilms in their natural environment. Biofilms are found in artificial environments as well as in their natural environment. Biofilms are aggregates of microorganisms surrounded by three-dimensional complex extracellular polymeric components that form on surfaces [1]. Food safety is a vital issue that directly affects public health and encompasses all segments of the food industry [2]. Biofilm formation causes problems in many areas of the food industry through energy loss, reduction in flow and heat transfer, and clogging of membranes. Many bacteria, both harmless and pathogenic, can form biofilms in the food environment $[2,3]$.

Even with careful cleaning of food processing equipment, it is very difficult or impossible to produce a microorganism-free food. This difficulty is due to the presence of biofilms in the units where the product is processed [4]. Biofilms can form in moist environments with minimal food debris. Once the biofilm has formed, the surfaces are much more difficult to clean due to the presence of extracellular components. Many cleaning procedures involve the removal of food residue from surfaces with chemical agents applied with hot or cold water. The cleaning process is accomplished with a single chemical or a combined application of chemicals and physical agitation (water turbulence or scrubbing) [5]. However, conventional cleaning and disinfection procedures may not be effective in biofilm control due to the high resistance of biofilms. There are many studies evaluating new biofilm control strategies in the food industry. In addition to mechanical and chemical applications, biological approaches such as enzymes, phages, interspecies interactions, and antimicrobial molecules of microbial origin are also being evaluated [6-8].

Numerous microorganisms can colonize on metal surfaces and form biofilms. Routine sanitation procedures prefer chemical agents or biocides to clean metal surfaces. Nevertheless, these strategies, including the addition of substances from outside, have some disadvantages [9]. Electrolysis is the direct electric current passing through an electrolyte, causing chemical reactions and decomposition of substances at the electrodes. The basic components needed to perform electrolysis are an electrolyte, electrodes, and a power source. The generation of electrolysis products such as chlorine, hydrogen peroxide, and sudden $\mathrm{pH}$ changes with direct current prevents the adhesion of bacteria or facilitates the detachment of biofilms from surfaces [10-13]. Electrochemical biofilm control is a technology for delaying or preventing the adhesion of microorganisms to a surface by 
altering their reactive properties or by removing adherent cells. This technology can be applied to surfaces which have electrical conductivity. These conductive surfaces behave like electrodes where electrochemical reactions occur. Thus, by applying a constant electric current to the surface, biofilm control can be possible continuously or for a certain period of time [14]. Current studies on electrochemical interactions of microbial biofilms include approaches to delaying the attachment of microbial cells or removing existing biofilms from surfaces. The generation of antimicrobial or antibiofilm agents on the adherent surface of biofilms may be a strategy to combat biofilms [15]. Antimicrobial agents may have difficulty diffusing into the inner layers of a biofilm when delivered from the fluid surrounding the biofilm. In situ generation of an antimicrobial or antibiofilm agent at the adherent site of a biofilm may be more efficient [10]. Electrolysis is one of the simplest ways to generate antimicrobial agents at a surface. Electrolysis of water can lead to local $\mathrm{pH}$ changes that can affect biofilms. Chlorine, an antimicrobial agent, can be generated by electrolysis in the presence of chlorine [16]. Electrolysis of aqueous solutions such as $\mathrm{NaCl}$ solution results in the generation of molecular oxygen, molecular hydrogen, hydrogen cations, hydroxyl anions and other reactive oxygen species as well as heat [17].

Damage to food processing equipment, product contamination, energy loss, and infectious diseases in clinical settings caused by microbial biofilms result in significant economic losses. Microbial biofilms that develop in food units cause significant financial losses by disrupting the textural properties of food products and leading to the spread of food-borne infection and intoxication diseases by being the source of continuous contamination. Attempting to remove biofilms using existing sanitation methods entails a financial burden due to the use of expensive chemicals and leads to contamination of food products due to intensive use of chemicals despite rinsing processes [18].

Electrochemical removal of biofilms is one of the most studied topics in the literature in the context of biofilm control. The aim of the study reported in this article was to shed light on the role of electrolysis products and biofilm removal at the anode or cathode. In this study, it was aimed to control and remove biofilms of some important food pathogens such as E. coli, S. Typhimurium and S. aureus, which significantly affect both human health and food quality.

\section{Materials and Methods}

\subsection{Bacterial strains}

The bacterial strains evaluated in the study were obtained from Ankara University, Faculty of Science, Department of Biology, Microbiology Research Laboratory Culture Collection. Two Gram- 
negative (Escherichia coli ATCC 25922, Salmonella Typhimurium DMC4) and one Gram-positive (Staphylococcus aureus ATCC 25923) reference strains were used in the studies.

\subsection{Optimization of biofilm formation}

First, the ideal biofilm production conditions for the three reference strains were optimized. $316 \mathrm{~L}$ type stainless steel surfaces, which are widely used in the food industry, were preferred as the surface for biofilm sampling [18].

E. coli colonies grown overnight at $37^{\circ} \mathrm{C}$ on BHI (Brain Heart Infusion, Merck, Germany) agar medium were harvested with a sterile loop and suspended in diluted (1:250) BHI (Brain Heart Infusion, Merck, Germany) medium to adjust MacFarland 2 (approximately $6.0 \times 10^{8}$ ). $5 \mathrm{~mL}$ of the suspended culture was taken and transferred to sterile glass tubes with $316 \mathrm{~L}$ type stainless steel coupons $(2.5 \mathrm{~cm} \times 0.8 \mathrm{~cm} \times 0.1 \mathrm{~cm})$. The tubes containing only medium and coupons were designed as negative controls. The test tubes were then incubated for $24 \mathrm{~h}$ at $37^{\circ} \mathrm{C}$ under static conditions [19].

An overnight $S$. Typhimurium culture (cultured in LB; Luria-Bertani without $\mathrm{NaCl}$ ) was reinoculated at a ratio of $5 \%(\mathrm{v} / \mathrm{v})\left(2.5 \times 10^{8} \mathrm{CFU} / \mathrm{mL}\right)$ into a new tube containing $5 \mathrm{~mL}$ of LB without $\mathrm{NaCl}$ medium. $5 \mathrm{~mL}$ of inoculated cultures were transferred to sterile glass tubes with $316 \mathrm{~L}$ type stainless steel coupons $(2.5 \mathrm{~cm} \times 0.8 \mathrm{~cm} \times 0.1 \mathrm{~cm})$. The test tubes were incubated for $24 \mathrm{~h}$ at $28{ }^{\circ} \mathrm{C}$ under static conditions [20].

An overnight $S$. aureus culture (cultured in TSB; Tryptic Soy Broth, Merck, Germany) was reinoculated at a ratio of $5 \%(\mathrm{v} / \mathrm{v})\left(2.5 \times 10^{7} \mathrm{CFU} / \mathrm{mL}\right)$ into a new tube containing $5 \mathrm{~mL}$ of TSB supplied with $1.5 \% \mathrm{NaCl}$ ). $5 \mathrm{~mL}$ of the cultures were transferred to sterile glass tubes with $316 \mathrm{~L}$ type stainless steel coupons $(2.5 \mathrm{~cm} \times 0.8 \mathrm{~cm} \times 0.1 \mathrm{~cm})$. The test tubes were then incubated for $24 \mathrm{~h}$ at 37 ${ }^{\circ} \mathrm{C}$ under static conditions [21].

For the current study 316L type stainless steel surface was preferred, which is widely used in the food industry. This material can be considered as a good electrode due to its high conductivity [22].

\subsection{Electrolysis of biofilms sampled on stainless steel surfaces}

After biofilm production was performed for each reference strain, the coupons were removed from the glass tubes under aseptic conditions and rinsed twice with sterile distilled water to remove planktonic cells. The experiment designed according to the method of Rabinovitch and Stewart [10] was modified. The rinsed coupons were connected to both the anode and cathode poles in a closed- 
circuit system in which a direct electrical current was provided for each biofilm. The electrolysis setup with biofilm samples at different poles is shown in Fig. 1. The coupons containing the biofilm samples were connected to the poles and immersed in a sterile $2 \mathrm{M} \mathrm{NaCl}$ buffer. The circuit was completed with a power supply and a $10 \mathrm{~V}$ potential was applied $(0.3 \mathrm{~A})$. Individual electrolysis setups were prepared for 1,2 , and 5 min treatment as test groups. The coupons were separately attached to both the anode and cathode, and the effects of different poles on biofilm removal were evaluated.

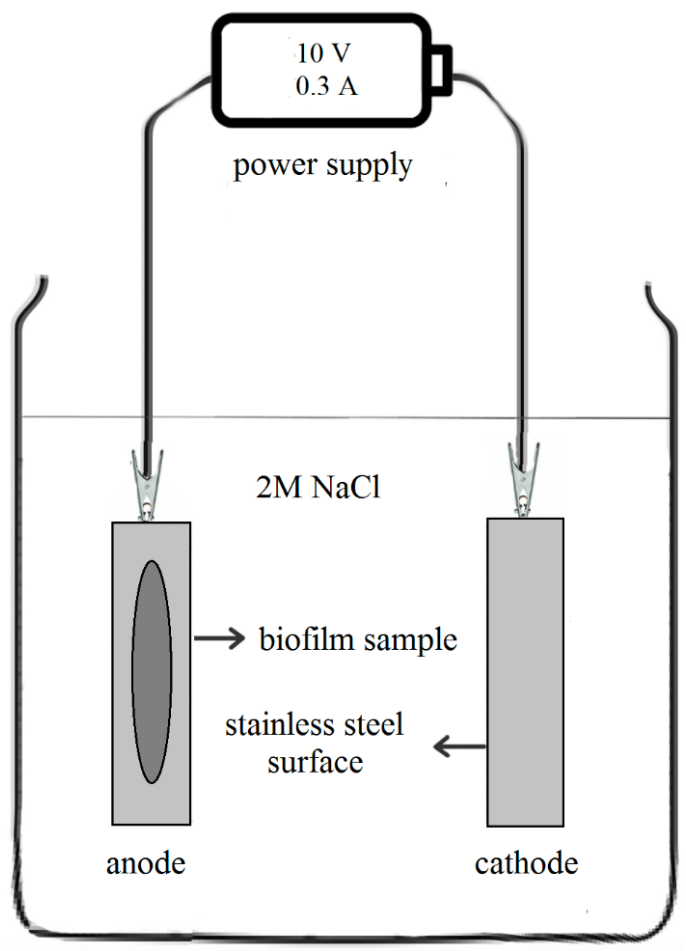

Figure 1: Schematic illustration of electrolysis setup

After applying a direct current, the coupons were washed and transferred under aseptic conditions to $50 \mathrm{~mL}-$ Falcon tubes containing $5 \mathrm{~mL}$ of sterile saline $(0.9 \% \mathrm{NaCl})$ and 10 grams of glass beads. The tubes were vortexed at the highest intensity for $2 \mathrm{~min}$ and serial dilutions were prepared from the biofilm suspensions. Colony forming units (CFU) were calculated using the spread plate method on TSA agar plates (Tryptic Soy Agar, Merck, Germany). The plates were incubated at $37^{\circ} \mathrm{C}$ for $24 \mathrm{~h}$. As positive control groups, no electric current was applied and the coupons were immersed in $2 \mathrm{M} \mathrm{NaCl}$ buffer for 1, 2, and $5 \mathrm{~min}$. The decrease in biofilm production compared to the control groups was determined by colony counting. Using the colony count results of the control 
groups, the log percent (\%) reductions of the test groups were calculated using the formula given: [(1-10- LR)] x 100 (LR: Logarithmic reduction; Logarithmic colony count of positive control groupsLogarithmic colony count of test groups).

\subsection{Determination of remaining biofilm matrix after electrolysis}

The crystal violet binding assay was used to detect the residual biofilm matrix remaining on the coupons after electrolysis. In the related study, the method proposed by [23] was modified. Biofilm sampling on the coupons was performed as described above. After incubation, the coupons were rinsed and subjected to the electrolysis process described above. After the process, the coupons were transferred to glass test tubes each containing $5 \mathrm{~mL}$ of $95 \%$ methanol and fixed for $10 \mathrm{~min}$ at room temperature. After this step, the coupons were transferred to glass test tubes containing $5 \mathrm{~mL}$ of $0.1 \%$ crystal violet solution (Merck, Germany). After the 30 -min incubation, the coupons were rinsed under running tap water to remove the remaining crystal violet dye. Following rinsing, the coupons were transferred to tubes each containing $5 \mathrm{~mL}$ of $33 \%$ glacial acetic acid solution. After a 15 min-incubation period, $200 \mu \mathrm{L}$ of the dissolved crystal violet dye was removed from the tubes and transferred to the wells of U-bottom microtiter plate (LP Italiana, Italy). The plates were read at 595 $\mathrm{nm}$ using an ELISA reader. As positive control groups, coupons were treated in the same way with biofilm samples that were not subjected to electrolysis. The sterile coupons were used as negative controls. The percentage reduction of biofilm matrix formation was calculated according to the given formula: $\{[(\mathrm{C}-\mathrm{B})-(\mathrm{T}-\mathrm{B})] /(\mathrm{C}-\mathrm{B})\} * 100(\mathrm{C}$; OD values from control group wells, B; OD values from blank well, T; OD values from test group wells). The crystal violet binding assay is an indirect method and provides information on the accumulation of extracellular polymeric components associated with the biofilm matrix on surfaces. In this context, it was possible to determine the remaining matrix components on surfaces after electrolysis.

\subsection{Antimicrobial effects of electrolyzed eater on planktonic bacterial cells}

In this study, $2 \mathrm{M} \mathrm{NaCl}$ solution electrolyzed according to the conditions in biofilm studies was applied to bacterial cells in planktonic form $(10 \mathrm{~V}, 0.3 \mathrm{~A}, 5 \mathrm{~min}) .1 \mathrm{~mL}$ of the active bacterial cultures were removed and transferred to the tubes containing $1 \mathrm{~mL}$ of fresh electrolyzed solution. After the tubes were incubated for $5 \mathrm{~min}$ at room temperature, serial dilutions were prepared from the suspensions and inoculation was performed using the spread plate method on TSA agar plates. The logarithmic and percentage reduction of colony number was calculated as described above. 


\subsection{Statistical analysis}

The results of the test and control groups were analyzed using One-WAY ANOVA and T tests. The changes in mean values were given as standard deviation. The results of biofilm cell eradication and matrix removal were compared using Pearson correlation. The confidence interval for tests was taken as $p<0.01$.

\section{Results}

\subsection{Electrolysis of biofilms sampled on stainless steel surfaces}

To test the efficacy of electrolysis treatment, 24 h-old $S$. Typhimurium, $S$. aureus, and E. coli biofilms were treated at the anode and cathode. The viable cell counts of the biofilms exposed to electrolysis were enumerated using the CFU assay. The reduction of viable cells (LR) for each treatment was then calculated by subtracting the number of viable cells of the untreated control biofilms. The logarithmic reduction was also calculated (Table 1). A graph of the log reduction is displayed in Fig. 2. The biofilm cells of $S$. Typhimurium and E. coli on the cathode pole were eliminated at all treatment intervals. The biofilms of $S$. Typhimurium and E. coli on the anode were eradicated only during prolonged treatment (Fig. 2a and Fig. 2c). Although mature S. aureus biofilms on the cathode were removed more, they could not be eradicated under the applied electrolysis conditions and in the preferred electrolysis buffer. However, a strong decrease in cell viability was observed for cathode samples (approximately $2 \log$ reduction) (Fig. 2b). Thus, all of the data indicated an increased trend of biofilm cell elimination for the compared anode samples.

Table 1: Logarithmic reductions (\%) of biofilm cells and removal (\%) of biofilm matrix after electrolysis

\begin{tabular}{|c|c|c|c|c|c|c|}
\hline \multirow[t]{2}{*}{ Strain } & \multicolumn{3}{|c|}{$\begin{array}{c}\text { Cathode Biofilm Cell } \\
\text { Log Reduction (\%) }\end{array}$} & \multicolumn{3}{|c|}{$\begin{array}{l}\text { Anode Biofilm Cell } \\
\text { Log Reduction (\%) }\end{array}$} \\
\hline & $1 \mathrm{~min}$ & $2 \mathrm{~min}$ & $5 \mathrm{~min}$ & $1 \mathrm{~min}$ & $2 \mathrm{~min}$ & $5 \mathrm{~min}$ \\
\hline$S$. Typhimurium DMC4 & 100.00 & 100.00 & 100.00 & $99.57 \pm 0.057$ & $92.76 \pm 1.54$ & 100.00 \\
\hline S. aureus ATCC 25923 & $99.29 \pm 0.27$ & $99.80 \pm 1.54$ & $99.66 \pm 2.01$ & $95.46 \pm 0.41$ & $97.70 \pm 2.50$ & $99.42 \pm 3.41$ \\
\hline E. coli ATCC 25922 & 100.00 & 100.00 & 100.00 & $99.999 \pm 2.52$ & 100.00 & 100.00 \\
\hline \multirow[t]{2}{*}{ Strain } & \multicolumn{3}{|c|}{$\begin{array}{c}\text { Cathode Biofilm } \\
\text { Matrix Reduction (\%) }\end{array}$} & \multicolumn{3}{|c|}{$\begin{array}{c}\text { Anode Biofilm } \\
\text { Matrix Reduction (\%) }\end{array}$} \\
\hline & $1 \mathrm{~min}$ & $2 \mathrm{~min}$ & $5 \mathrm{~min}$ & $1 \mathrm{~min}$ & $2 \mathrm{~min}$ & $5 \mathrm{~min}$ \\
\hline$S$. Typhimurium DMC4 & $94.67 \pm 4.57$ & $97.81 \pm 3.22$ & 100.00 & $86.36 \pm 7.57$ & $88.75 \pm 6.55$ & $95.16 \pm 9.51$ \\
\hline S. aureus ATCC 25923 & $72.27 \pm 3.44$ & $85.69 \pm 6.41$ & $93.79 \pm 7.83$ & $75.88 \pm 5.55$ & $80.53 \pm 6.41$ & $84.22 \pm 4.15$ \\
\hline E. coli ATCC 25922 & $88.30 \pm 2.42$ & 100.00 & 100.00 & $83.74 \pm 4.47$ & $86.26 \pm 3.77$ & 100.00 \\
\hline
\end{tabular}


S. Typhimurium DMC4

$\mathbf{a}$

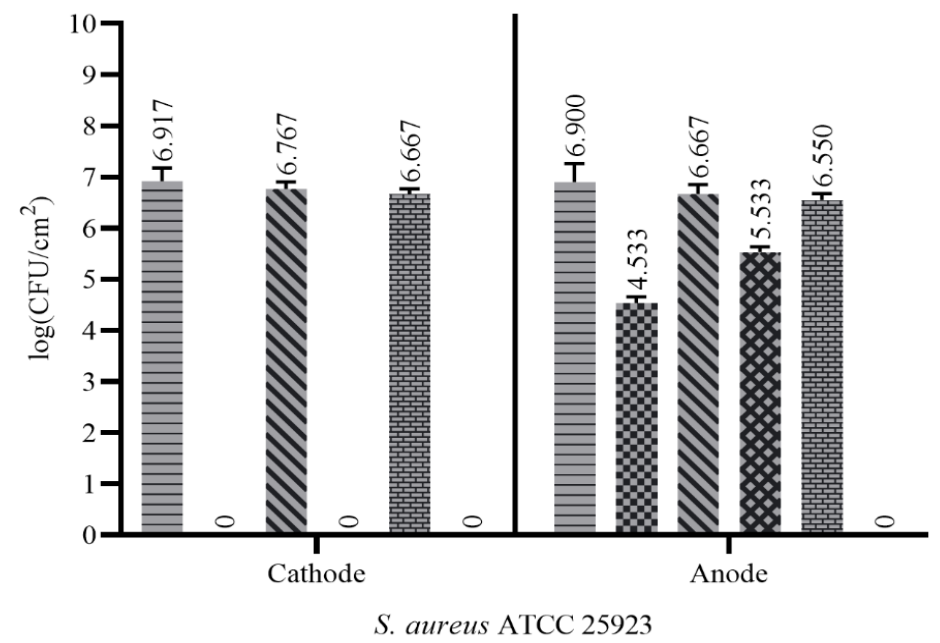

b

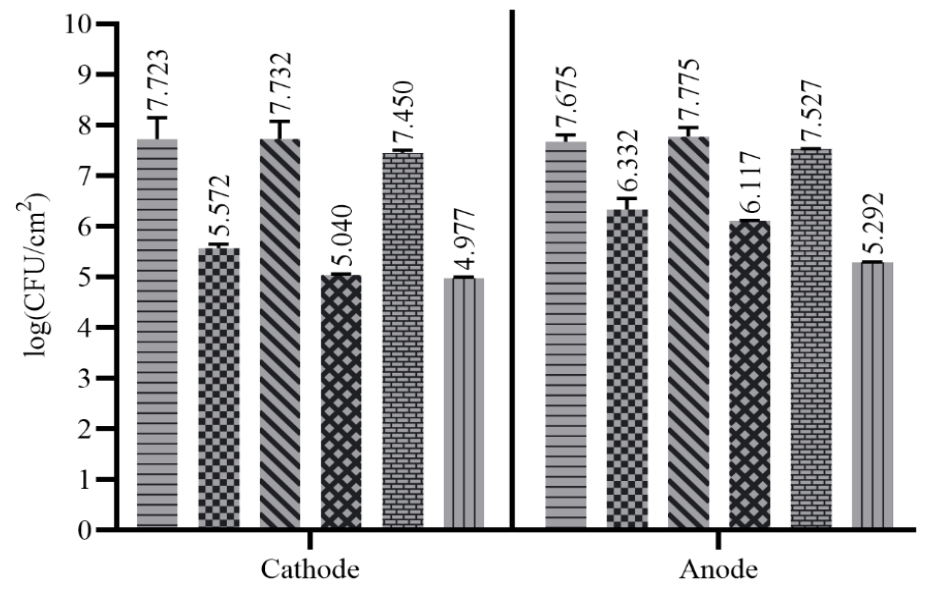

E. coli ATCC 25922

c

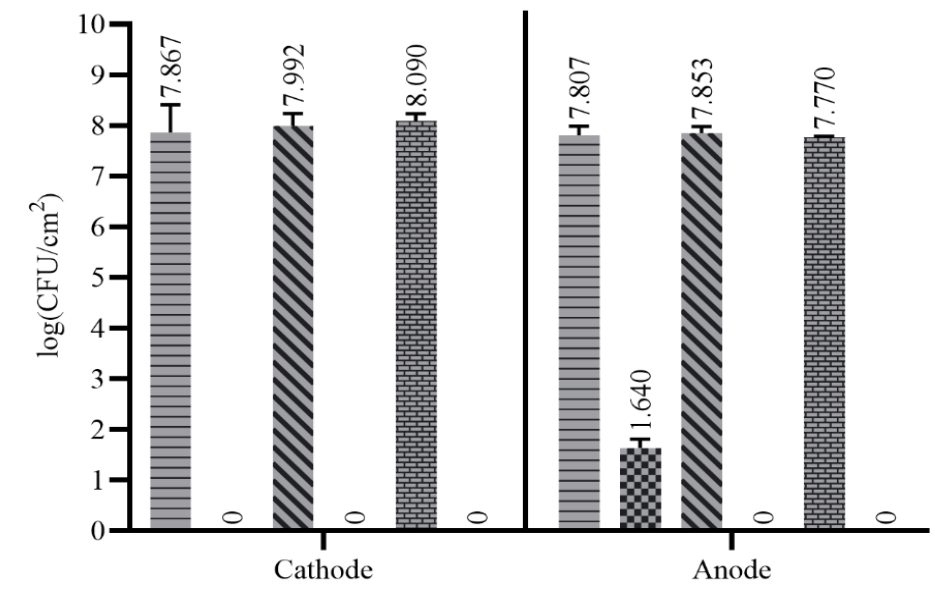

- Control-1 min

1. Electrolysis-1 min

IV Control-2 min

×x Electrolysis-2 min

职 Control-5 min

IIII Electrolysis-5 min

\author{
- Control-1 min \\ 0. Electrolysis-1 min \\ IV Control-2 min \\ ×x Electrolysis-2 min \\ 竪 Control-5 min \\ IIII Electrolysis-5 min
}

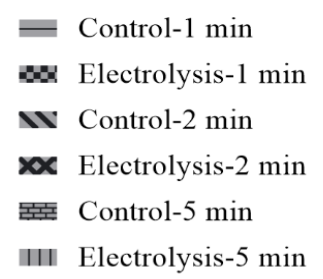

Figure 2: Effects of electrolysis on biofilm cells (a) Log reduction of $S$. Typhimurium biofilm cells on the cathode and anode (b) Log reduction of S. aureus biofilm cells on the cathode and anode (c) Log reduction of E. coli biofilm cells on the cathode and anode. Drastic log reductions have been observed in test groups compared with control groups (One-WAY ANOVA and T-Test; $p<0.01$ ) 


\subsection{Determination of remaining biofilm matrix after electrolysis}

After treatment with electrolysis, biofilms were quantified by the crystal violet staining method. The controls, treatment with only $2 \mathrm{M} \mathrm{NaCl}$ solution for 1,2 , and $5 \mathrm{~min}$, were also stained. The results of this experiment are shown in Fig. 3 and Table 1. Figure 3 shows the total matrix of biofilms for the different treatments applied. Efficient removal of the biofilm matrix was achieved only at the cathode. E. coli and S. Typhimurium biofilm matrix were removed from the stainless-steel surfaces with 5 min electrolysis treatment (Fig. 3a and 3c). It was also demonstrated that the efficacy of electrolysis, as measured by the crystal violet staining method and the colony forming unit assay, was proportional to the application time. Thus, a positive correlation was found between biofilm cell eradication rates and matrix removal of biofilms (Pearson correlation, $p<0.01$ ). It was not possible to remove the $S$. aureus biofilm matrix from the surfaces by electrolysis.

\subsection{Antimicrobial effects of electrolyzed water on planktonic bacterial cells}

Planktonic cells of $S$. Typhimurium, E. coli, and $S$. aureus could be completely killed when treated with $2 \mathrm{M} \mathrm{NaCl}$ solution electrolyzed at $10 \mathrm{~V}$ direct current for $5 \mathrm{~min}$. A 10-log reduction in populations compared to the control groups indicated that the respective electrolyte buffer and electrolysis procedure were effective on planktonic cultures of these pathogens (Table 2).

Table 2: Antibacterial effects of electrolyzed $\mathrm{NaCl}$ solution on planktonic bacterial cells

\begin{tabular}{lcccc}
\hline \multicolumn{1}{c}{ Strain } & $\begin{array}{c}\text { Control } \\
\text { Log }(\text { CFU/mL) }\end{array}$ & $\begin{array}{c}\text { Treatment } \\
\text { Log }(\text { CFU/mL) }\end{array}$ & $\begin{array}{c}\text { Log } \\
\text { Reduction }\end{array}$ & Log Reduction (\%) \\
\hline S. Typhimurium DMC 4 & $10.55 \pm 0.069$ & 0.00 & 10.55 & 100.00 \\
\hline S. aureus ATCC 25923 & $10.34 \pm 0.189$ & 0.00 & 10.34 & 100.00 \\
\hline E. coli ATCC 25922 & $10.50 \pm 0.281$ & 0.00 & 10.50 & 100.00 \\
\hline
\end{tabular}

Results were given as mean values with standard deviations. 
$S$. Typhimurium DMC4

$\mathbf{a}$

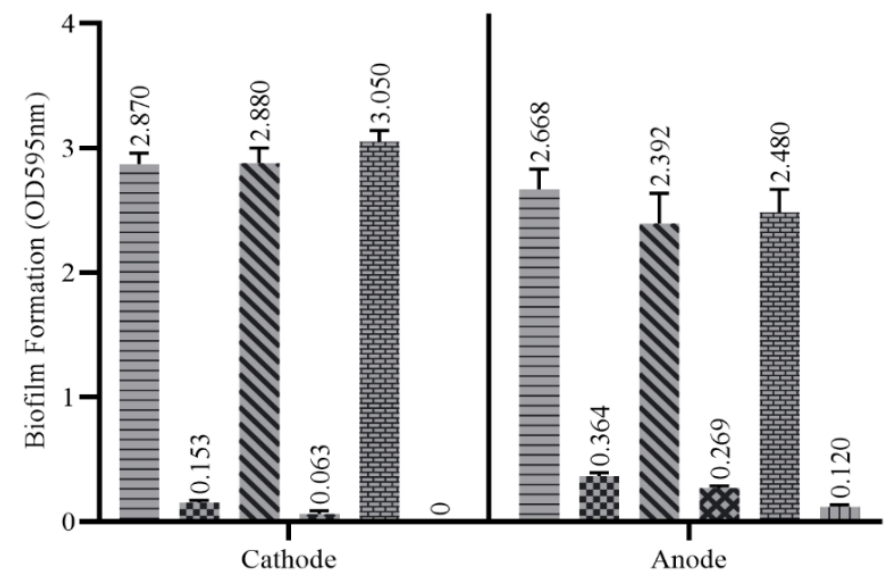

S. aureus ATCC 25923

b

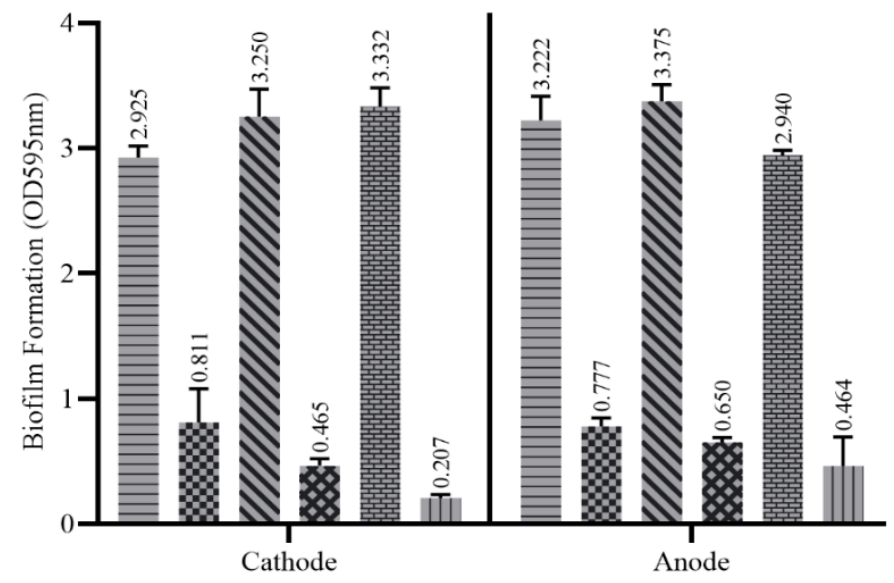

E. coli ATCC 25922

c

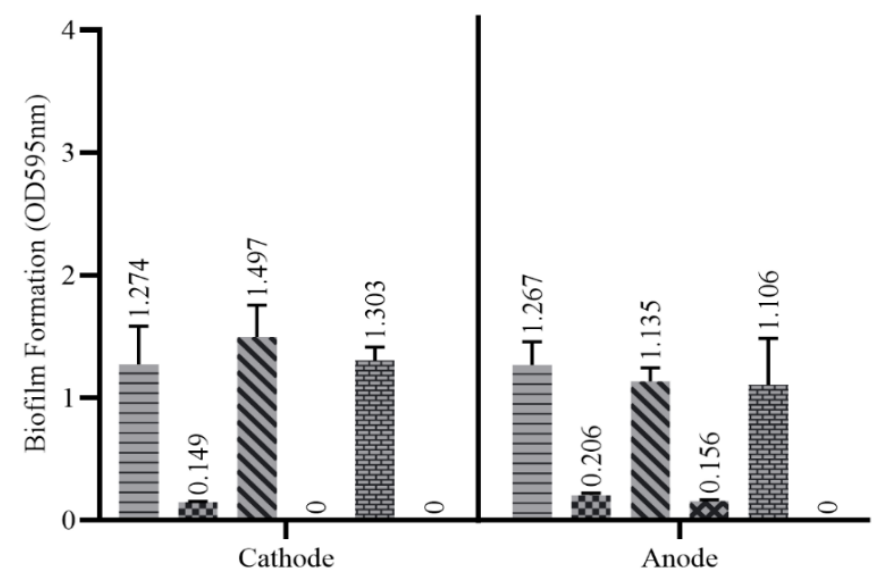

= Control-1 min

as Electrolysis-1 min

Iv Control-2 min

× Electrolysis-2 min

監 Control-5 min

IIII Electrolysis-5 min
60 Control-1 min
W Clectrolysis-1 min
× Electrol-2 min
5 Control-5 min
III Electrolysis-5 min

\author{
- Control-1 min \\ 60. Electrolysis-1 min \\ Iv Control-2 min \\ ×C Electrolysis-2 min \\ 勒 Control-5 min \\ III Electrolysis-5 min
}

Figure 3: Effects of electrolysis on biofilm matrix (a) Matrix reduction of $S$. Typhimurium biofilm on the cathode and anode (b) Matrix reduction of S. aureus biofilm on the cathode and anode (c) Matrix reduction of $E$. coli biofilm on the cathode and anode. Biomass reductions have been observed in test groups compared with control groups (One-WAY ANOVA and T-Test; $p<0.01$ ) 


\section{Discussion}

There are several ways to control biofilm development depending on electrochemical strategies considered in the literature. Most of these methods focus either on delaying/preventing cell adhesion or removing/eradicating the biofilm [24]. An effective strategy for electrochemical biofilm control is the application of a steady potential that results in the formation of biocides on the electrodes. As a result of this phenomenon, a constant current can remove established biofilms from electrode surfaces [25]. The generation of potent antimicrobial agents from $\mathrm{NaCl}$ buffer is possible by electrolysis. The expected reaction is $2 \mathrm{H}_{2} \mathrm{O}+2 \mathrm{e}^{-} \rightarrow 2 \mathrm{OH}^{-}+\mathrm{H}_{2}$ at the anodic site. Thus, $\mathrm{pH}$ increase and hydrogen gas production may occur at the anode. On the other hand, the essential reaction is $\mathrm{H}_{2} \mathrm{O}+\mathrm{Cl}^{-} \rightarrow \mathrm{HOCl}+$ $\mathrm{H}^{+}+2 \mathrm{e}^{-}$. This reaction leads to a $\mathrm{pH}$ decrease and the formation of hypochlorous acid, a strong antimicrobial substance. $[10,24]$. The hypochlorous acid that can be generated at the cathode has a remarkable effect on viable cells found in biofilms [10]. The results of this study are similar to the results of the study by Rabinovitch and Stewart [10] in terms of better elimination of biofilm cells at the cathode than at the anode. The direct current efficacy observed in this study is also explained by the electrolytic production of chlorine. However, the DC biocidal agents produced were more effective in terms of removing Gram-negative biofilms such as E. coli and $S$. Typhimurium (Fig. 2). As an effective antimicrobial agent, chlorine has been documented to partially destroy biofilms of $S$. aureus and this study further confirms these findings [26]. This research investigated the use of direct current under highly concentrated $\mathrm{NaCl}(2 \mathrm{M} \mathrm{NaCl})$. Although previous biofilm studies in this area typically used a chloride-free solution to mitigate electrolysis effects, a standard saline solution (0.9 percent $\mathrm{NaCl}$ ) was also used to simulate physiologically important conditions. [27]. In contrast to these existing approaches, the high concentration of $\mathrm{NaCl}$ used in our experiments provided the best results in terms of eliminating E. coli, $S$. Typhimurium and $S$. aureus biofilms. In the preliminary study design, $\mathrm{NaCl}$ solutions of different concentrations were first subjected to electrolysis, and the most optimal result was obtained for $2 \mathrm{M} \mathrm{NaCl}$ (data not shown).

In addition, our results showed improved detachment of the biofilm matrix by electrolysis. With direct current application due to locally charged molecular vibrations, these findings also indicated increased permeability of the exopolysaccharide matrix. Giladi et al. [28] confirmed this finding. In other studies, thermal stimuli generated at the electrodes during electrolysis have been found to have an enhanced effect on biomass removal [29]. In general, due to their complex structures and diverse stimuli, it is difficult to investigate the mechanisms underlying the effect of electrolysis on biofilms [30, 31]. Matrix-assembling extracellular polymeric substances (EPS) immobilize biofilm 
cells, holding them in close proximity in the long term and thus enabling intense interactions, including cell-cell contact, horizontal gene transfer, and the formation of synergistic microconsortia [32]. Plastics, rubber, glass, wood, paper, cement and stainless steel are commonly used materials in the food industry, the latter being the most commonly used material for food machinery and utensils due to its hygienic properties $[33,34]$. The low hygienic level of contact surfaces leads to the accumulation of organic material, which contributes to the attachment of microbes. When the biofilm formation is allowed to occur, the presence of adherent EPS makes surface cleaning more difficult. If the organic residues on the surface are not effectively cleaned, microorganisms can continuously adhere to these areas [35]. Although E. coli and $S$. Typhimurium biofilm matrix structures in particular were shown to be effectively removed from stainless steel surfaces by electrolysis, this application alone could not destroy a biofilm with all its components (Fig. 3 and Table 1).

\section{Conclusion}

In this study, it was clarified that it was possible to electrochemically control biofilms of some important food pathogenic bacteria such as E. coli, S. Typhimurium, and S. aureus, which significantly affect both human health and food quality due to the presence of biofilms in food processing facilities. To increase the electrochemical removal efficiency, $\mathrm{NaCl}$ was used in the electrolyte buffer because it is cheap and reliable. In this way, a low-cost approach and electrochemical reactions were used to obtain reliable doses of biocidal agents and test their efficacy on biofilm samples. The result is an alternative to highly toxic and expensive chemicals commonly used in cleaning-in-place processes in the food industry.

\section{References}

[1] Sutherland, I.W., The biofilm matrix-an immobilized but dynamic microbial environment, Trends in Microbiology, 9(5), 222-227, 2001.

[2] Mizan, M.F.R., Jahid, I.K., Ha, S.D., Microbial biofilms in seafood: a food-hygiene challenge, Food Microbiology, 49, 41-55, 2015.

[3] Poulsen, L.V., Microbial biofilm in food processing, LWT-Food Science and Technology, 32(6), 321-326, 2001.

[4] Brooks, J.D., Flint, S.H., Biofilms in the food industry: problems and potential solutions, International Journal of Food Science \& Technology, 43(12), 2163-2176, 2008.

[5] Chmielewski, R.A.N., Frank, J.F., Biofilm formation and control in food processing facilities, Comprehensive Reviews in Food Science and Food Safety, 2(1), 22-32, 2003. 
[6] Simões, M., Simões, L.C., Vieira, M.J., A review of current and emergent biofilm control strategies, LWT-Food Science and Technology, 43(4), 573-583, 2010.

[7] Jahid, I.K., Ha, S.D., A review of microbial biofilms of produce: future challenge to food safety, Food Science and Biotechnology, 21(2), 299-316, 2012.

[8] Srey, S., Jahid, I.K., Ha, S.D., Biofilm formation in food industries: a food safety concern, Food Control, 31(2), 572-585, 2013.

[9] Lewandowski, Z., Beyenal, H., Fundamentals of biofilm research, CRC Press. Boca Raton, FL. 2014.

[10] Rabinovitch, C., Stewart, P.S., Removal and inactivation of Staphylococcus epidermidis biofilms by electrolysis, Applied and Environmental Microbiology, 72(9), 6364-6366, 2006.

[11] Liu, W.K., Brown, M.R., Elliott, T.S., Mechanisms of the bactericidal activity of low amperage electric current (DC), The Journal of Antimicrobial Chemotherapy, 39(6), 687-695, 2001.

[12] Stoodley, P., deBeer, D., Lappin-Scott, H.M., Influence of electric fields and pH on biofilm structure as related to the bioelectric effect, Antimicrobial Agents and Chemotherapy, 41(9), 18761879, 1997.

[13] Poortinga, A.T., Smit, J., van der Mei, H.C., Busscher, H.J., Electric field induced desorption of bacteria from a conditioning film covered substratum, Biotechnology and Bioengineering, 76(4), 395-399, 2001.

[14] Hong, S.H., Jeong, J., Shim, S., Kang, H., Kwon, S., Ahn, K.H., Yoon, J., Effect of electric currents on bacterial detachment and inactivation, Biotechnology and Bioengineering, 100(2), 379386, 2008.

[15] Stewart, P.S., G.A. McFeters, C.T., J.D., Bryers (ed.), Huang, Biofilm control by antimicrobial agents, Biofilms II: process analysis and applications. Wiley-Liss, New York, N.Y., 373p-405p, 2000.

[16] Lim, T.K., Murakami, T., Tsuboi, M., Yamashita, K., Matsunaga, T., Preparation of a colored conductive paint electrode for electrochemical inactivation of bacteria, Biotechnology and Bioengineering, 81(3), 299-304, 2003.

[17] Stewart, P.S., Wattanakaroon, W., Goodrum, L., Fortun, S.M., McLeod, B.R., Electrolytic generation of oxygen partially explains electrical enhancement of tobramycin efficacy against Pseudomonas aeruginosa Biofilm, Antimicrobial Agents and Chemotherapy, 43(2), 292-296, 1999.

[18] Kumar, C.G., Anand, S.K., Significance of microbial biofilms in food industry: a review, International Journal of Food Microbiology, 42(1-2), 9-27, 1998.

[19] Crémet, L., Corvec, S., Batard, E., Auger, M., Lopez, I., Pagniez, F., Caroff, N., Comparison of three methods to study biofilm formation by clinical strains of Escherichia coli, Diagnostic Microbiology and Infectious Disease, 75(3), 252-255, 2013. 
[20] Vestby, L.K., Møretrø, T., Langsrud, S., Heir, E., Nesse, L.L., Biofilm forming abilities of Salmonella are correlated with persistence in fish meal-and feed factories, BMC Veterinary Research, 5(1), 20, 2009.

[21] Onbas, T., Osmanagaoglu, O., Kiran, F., Potential properties of Lactobacillus plantarum F-10 as a Bio-control strategy for wound infections, Probiotics and Antimicrobial Proteins, 11(4), 1110-1123, 2018.

[22] Istanbullu, O., Babauta, J., Duc Nguyen, H., Beyenal, H., Electrochemical biofilm control: mechanism of action, Biofouling, 28(8), 769-778, 2012.

[23] Stepanović, S., Vuković, D., Dakić, I., Savić, B., Švabić-Vlahović, M., A modified microtiter-plate test for quantification of staphylococcal biofilm formation, Journal of Microbiological Methods, 40(2), 175-179, 2000.

[24] Sultana, S.T., Babauta, J.T., Beyenal, H., Electrochemical biofilm control: a review, Biofouling, 31(9-10), 745-758, 2015.

[25] Dhar, H.P., Bockris, J.O., Lewis, D.H., Electrochemical inactivation of marine bacteria, Journal of the Electrochemical Society, 128(1), 229, 1981.

[26] Ueda, S, Kuwabara, Y., Susceptibility of biofilm Escherichia coli, Salmonella enteritidis and Staphylococcus aureus to detergents and sanitizers, Biocontrol Science 12(4), 149$153,2007$.

[27] Sandvik, E.L., McLeod, B.R., Parker, A.E., Stewart, P.S., Direct electric current treatment under physiologic saline conditions kills Staphylococcus epidermidis biofilms via electrolytic generation of hypochlorous acid, PloS one, 8(2), e55118, 2013.

[28] Giladi, M., Porat, Y., Blatt, A., Shmueli, E., Wasserman, Y., Kirson, E.D., and Palti, Y., Microbial growth inhibition by alternating electric fields in mice with Pseudomonas aeruginosa lung infection, Antimicrobial Agents and Chemotherapy, 54(8), 3212-3218, 2010.

[29] Caubet, R., Pedarros-Caubet, F., Chu, M., Freye, E., de Belem Rodrigues, M., Moreau, J.M., Ellison, W.J., A radio frequency electric current enhances antibiotic efficacy against bacterial biofilms, Antimicrobial Agents and Chemotherapy, 48(12), 4662-4664, 2004.

[30] Del Pozo, J.L., Rouse, M.S., Patel, R., Bioelectric effect and bacterial biofilms. A systematic review, The International Journal of Artificial Organs, 31(9), 786-795, 2008.

[31] Del Pozo, J.L., Rouse, M.S., Euba, G., Greenwood-Quaintance, K.E., Mandrekar, J.N., Steckelberg, J.M., Patel, R., Prevention of Staphylococcus epidermidis biofilm formation using electrical current, Journal of Applied Biomaterials \& Functional Materials, 12(2), 81-83, 2014.

[32] Flemming, H.C., Wingender, J., The biofilm matrix, Nature Reviews Microbiology, 8(9), 623-633, 2010.

[33] Holah, J.T., Thorpe, R.H., Cleanability in relation to bacterial retention on unused and abraded domestic sink materials, Journal of Applied Bacteriology, 69(4), 599-608, 1990. 
[34] Van Houdt, R., Michiels, C.W., Biofilm formation and the food industry, a focus on the bacterial outer surface, Journal of Applied Microbiology, 109(4), 1117-1131, 2010.

[35] Boyd, R.D., Cole, D., Rowe, D., Verran, J., Paul, A.J., West, R.H., Cleanability of soiled stainless steel as studied by atomic force microscopy and time of flight secondary ion mass spectrometry, Journal of Food Protection, 64(1), 87-93, 2001. 